\title{
A Hope for an Integrated Taxonomy of Fossil and Extant Clam Shrimps
}

\author{
Gang Li ${ }^{*}$, Xiao Teng ${ }^{2,3}$ \\ ${ }^{1}$ State Key Laboratory of Palaeobiology and Stratigraphy, Center for Excellence in Life and Palaeoenvironment, Nanjing Institute \\ of Geology and Palaeontology, Nanjing, China \\ ${ }^{2}$ CAS Key Laboratory of Economic Stratigraphy and Palaeogeography, Nanjing Institute of Geology and Palaeontology and Center \\ for Excellence in Life and Paleoenvironment, Chinese Academy of Sciences, Nanjing, China \\ ${ }^{3}$ University of Science and Technology of China, Hefei, China \\ Email: *gangli@nigpas. ac.cn
}

How to cite this paper: Li, G. and Teng, X. (2019) A Hope for an Integrated Taxonomy of Fossil and Extant Clam Shrimps. Open Journal of Geology, 9, 609-612. https://doi.org/10.4236/ojg.2019.910054

Received: August 16, 2019

Accepted: September 20, 2019

Published: September 23, 2019

Copyright (c) 2019 by author(s) and Scientific Research Publishing Inc. This work is licensed under the Creative Commons Attribution International License (CC BY 4.0).

http://creativecommons.org/licenses/by/4.0/

\section{(c) (i) Open Access}

\begin{abstract}
Clam shrimps are large bivalved branchiopod crustacean. They first occurred in the Devonian, and flourished during the Mesozoic in Asia. Fossil clam shrimps play an important role in the subdivision and correlation of non-marine fossil-bearing strata. The phosphatized carapaces or carapace external/internal moulds are the main objects for taxonomical studies. The delicate ornament and the ontogenetically developing morphological patterns on the growth bands of carapaces are the main fossil taxonomic criteria. While modern clam shrimp taxonomy is based on soft body morphological features and molecular data, which could not be found in the fossil records. This makes it difficult to discuss the fossil and modern clam shrimp phylogenetic relationship. Nowadays scanning electron microscopes are widely available, and can play an important role in investigating clam shrimp carapace morphology which could be common language to integrate fossil and modern taxonomy.
\end{abstract}

\section{Keywords}

Clam Shrimps, Fossil, Extant, Taxonomy

\section{Introduction}

Clam shrimps are large branchiopod crustaceans. They have laterally compressed shrimp-like bodies which are enclosed in chitinous bivalved carapace. This is the reason why they are called clam shrimps. Extant clam shrimps are widely distributed on all continents except for Antarctica, but fossil clam shrimps are widely distributed, and they were also found in Antarctica. Accord- 
ing to the fossil records, clam shrimps extend back to the Devonian Period. The evolution of clam shrimps was initially centred on Europe, but in Mesozoic they diversified more rapidly in Asia [1]. During the Cenozoic they gradually declined with very scarce fossil records [2], and resulted in both low abundance and diversity. Nowadays only fourteen genera in five families remain [1].

\section{Living Environment of Clam Shrimps}

Clam shrimps inhabit seasonally astatic wetlands such as playas, vernal (rain and snow-melt) pools, rice field or fishless lakes [3]. This living environment is consistent with their relatively short life cycles. Their resting eggs are able to survive dormant for several years under dry conditions. All these special features make clam shrimps the very successful colonizers of ephemeral freshwater ecosystems [4] under a wet and dry alternating climate setting in the earth history [5]. This results in very abundant fossil records worldwide in the Mesozoic fine lacustrine deposits [6]-[11].

\section{Taxonomy of Fossil and Extant Clam Shrimps}

Clam shrimp fossil records demonstrate that their fossilized soft parts are very rare. Most common cases are that they are preserved as phosphatized carapaces [12], or the external or internal moulds of carapaces. Thus, the classification and taxonomy of fossil clam shrimps are mainly based on the morphological characters of their carapaces, such as the carapace outline, structure and the fine ornamentation patterns on growth bands [5]. While extant clam shrimps are classified based on the soft body morphological characters and molecular data. In order to solve this dilemma, a common language should be found for an integrated classification for fossil and extant clam shrimps [13]. During The Crustacean Society Mid-Year Meeting (May 2019 Hong Kong), fossil and extant clam shrimp specialists have carried out detailed discussion about the future research on clam shrimp taxonomy. Most participants agreed that clam shrimp carapaces could be the main object for searching for morphological features to discuss the relationship between fossil and modern clam shrimps.

Nowadays scanning electron microscopes (SEMs) are widely available and play a more important role in taxonomy of fossil clam shrimps [14]. The previous studies of fossil clam shrimps, mainly based on the observation under a light microscope, made un-precise descriptions of carapace ornamentation features, and thus taxonomic relationships cannot be determined clearly. A new SEM imaging of the type material of Neodiestheria dalaziensis from the Albian Dalazi Formation in northern China has revealed ontogenetically developing morphological patterns on growth bands of the juvenile stage of the carapace, which indicate that Neodiestheria is closely related phylogenetically to Triglypta [15]. This shows us that further investigation on the fossil and extant clam shrimp carapaces by the help of SEM could get more fruitful results to discuss their phylogenetic relationship. 


\section{Acknowledgements}

The study was supported by the Strategic Priority Research Program of the Chinese Academy of Sciences (XDB26000000) and the National Natural Science Foundation of China $(41572006,41688103,41972007)$. This is a contribution to UNESCO-IUGS IGCP Project 679.

\section{Conflicts of Interest}

The authors declare no conflicts of interest regarding the publication of this paper.

\section{References}

[1] Chen, P.J., Li, G. and Batten, D.J. (2007) Evolution, Migration and Radiation of Late Mesozoic Conchostracans in East Asia. Geological Journal, 42, 391-413. https://doi.org/10.1002/gj.1064

[2] Shen, Y.B., Gallego, O.F., Buchheim, H.P. and Biaggi, R.E. (2006) Eocene Conchostracans from the Laney Member of the Green River Formation, Wyoming, USA. Journal of Paleontology, 80, 447-454. https://doi.org/10.1666/0022-3360(2006)80[447:ECFTLM]2.0.CO;2

[3] Brendonck, L., Rogers, D.C., Olesen, J., Weeks, S.C. and Hoeh, R. (2008) Global Diversity of Large Branchiopods (Crustacea: Branchiopoda) in Fresh Water. $\mathrm{Hy}$ drobiologia, 595, 167-176. https://doi.org/10.1007/s10750-007-9119-9

[4] Guériau, P., Robet, N., Clément, G, Lagebro, L., Vannier, J., Briggs, D.E.G., Charbonnier, S., Olive, S. and Béthoux, O. (2016) A 365-Million-Year-Old Freshwater Community Reveals Morphological and Ecological Stasis in Branchiopod Crustaceans. Current Biology, 26, 383-390. https://doi.org/10.1016/j.cub.2015.12.039

[5] Li, G. (2017) Revision of Fossil Clam Shrimp Taxonomy and a Case Study on Palaobiogeography of Jurassic Clam Shrimps in China. Journal of Environment and Bio Research, 1, 1-6.

[6] Li, G. and Matsuoka, A. (2015) Searching for a Non-Marine Jurassic/Cretaceous Boundary in Northeastern China. Journal of Geological Society of Japan, 121, 109-122. https://doi.org/10.5575/geosoc.2015.0001

[7] Li, G. and Matsuoka, A. (2012) Jurassic Clam Shrimp (“Conchostracan”) Faunas in China. Science Report of Niigata University (Geology), 27, 73-88.

[8] Boukhalfa, K., Li, G., Ben Ali, W. and Soussi, M. (2015) Early Cretaceous Spinicaudatans ("Conchostracans") from Lacustrine Strata of the Sidi Aïch Formation in the Northern Chotts Range, Southern Tunisia: Taxonomy, Biostratigraphy and Stratigraphic Implication. Cretaceous Research, 56, 482-490. https://doi.org/10.1016/j.cretres.2015.06.006

[9] Gallego, O.F., Monferran, M.D., Astrop, T.I. and Zacarias, I.A. (2013) Reassignment of Lioestheria codoensis Cardoso (Spinicaudata, Anthronestheriidae) from the Lower Cretaceous of Brazil: Systematics and Paleoecology. Revista Brasileira de Paleontologia, 16, 47-60. https://doi.org/10.4072/rbp.2013.1.04

[10] Schneider, J.W. and Scholze, F. (2016) Late Pennsylvanian-Early Triassic Conchostracan Biostratigraphy: A Preliminary Approach. Geological Society, London, Special Publications, 450, 450-456. https://doi.org/10.1144/SP450.6

[11] Scholze, F., Golubev, V.K., Niedźwiedzki, G., Sennikov, A.G., Schneider, J.W. and Silantiev, V.V. (2015) Early Triassic Conchostracans (Crustacea: Branchiopoda) 
from the Terrestrial Permian-Triassic Boundary Sections in the Moscow Syncline. Palaeogeography Palaeoclimatology Palaeoecology, 429, 22-40. https://doi.org/10.1016/j.palaeo.2015.04.002

[12] Stigall, A.L., Babcock, L.E., Briggs, D.E.G. and Leslie, S.A. (2008) Taphonomy of Lacustrine Interbeds in the Kirkpatrick Basalt (Jurassic), Antarctica. Palaios, 23, 344-355. https://doi.org/10.2110/palo.2007.p07-029r

[13] Astrop, T.I. and Hegna, T.A. (2015) Phylogenetic Relationships between Living and Fossil Spinicaudatan Taxa (Branchiopoda Spinicaudata): Reconsidering the Evidence. Journal of Crustacean Biology, 35, 339-354.

https://doi.org/10.1163/1937240X-00002317

[14] Li, G. (2017) SEM Plays an Important Role in the Study of Fossil Clam Shrimps. Journal of Environmental Geology, 1, 22-23. https://doi.org/10.4172/2591-7641.1000006

[15] Li, G., Ohta, T., Batten, D.J., Sakai, T. and Kozai, T. (2016) Morphology and Phylogenetic Origin of the Spinicaudatan Neodiestheria from the Lower Cretaceous Dalazi Formation, Yanji Basin, North-Eastern China. Cretaceous Research, 62, 183-193. https://doi.org/10.1016/j.cretres.2015.09.019 